\title{
Bemoeizorg \\ en ambulante \\ onvrijwillige zorg
}

\section{De verpleeghuissector begint de implementatie van de Wet zorg en dwang ter hand te nemen in de thuiszorg. Welke praktische omstandigheden en voorwaarden kunnen daarbij aan de orde zijn?}

auteur

Arie Berg

verpleegkundig specialist ggz, Zorggroep Solis, Deventer
N 2020 WAS HET ZOVER: DE

invoering van de Wet verplichte ggz

(Wvggz) en de Wet zorg en dwang (Wzd) als vervanging van de Wet Bopz. ${ }^{1}$ De Wzd is bedoeld voor mensen met dementie of een verstandelijke beperking. Ggz-instellingen waren tot dan toe de aangewezen partij voor gedwongen zorg, ook voor deze patiëntengroepen, maar ze hebben er in meerderheid voor gekozen de Wzd niet uit te voeren. Ze richten zich uitsluitend nog op de Wvggz en leveren alleen crisisinterventie als er sprake is of lijkt te zijn van cognitieve stoornissen. Daarmee neemt de psychiatrie goeddeels afscheid van de zorg voor mensen met dementie, inclusief de gedwongen zorg die daarbij soms nodig is. Die zorg wordt overgelaten aan de verpleeghuissector. Deze sector heeft zich in het eerste jaar na de invoering vooral gericht op de interne situatie: de verpleeghuizen. De Covid-19-lockdown heeft de implementatie van de Wzd danig gefrustreerd. In de tweede helft van 2021 wordt ook de ambulante implementatie ter hand genomen; in de thuiszorg die aan deze sector verbonden is.

Dit artikel beschrijft praktische omstan- digheden en voorwaarden die daarbij aan de orde (kunnen) zijn. Dat gebeurt vanuit ervaringen binnen de ouderenpsychiatrie.

\section{Achtergrond}

Sinds mensenheugenis, in elk geval sinds de invoering van de Krankzinnigenwet in 1884, gaan psychiaters en de psychiatrie over gedwongen opname en behandeling van 'geesteszieken'. Ook de Wet Bopz, die tot 2020 van kracht was, liet daar geen twijfel over bestaan. De uitvoeringsorganisatie voor gedwongen opname was aanvankelijk de Sociaal Psychiatrische Dienst (SPD) van de Gemeentelijke Geneeskundige en Gezondheidsdienst (GGD). Later werd dit onderdeel van de Regionale Instelling voor Ambulante Geestelijke Gezondheidszorg (RIAGG), die vervolgens fuseerde met het algemeen psychiatrisch ziekenhuis tot de ggz-instellingen zoals wij die nu kennen.

Tot de invoering van de Wzd ontfermde de ggz zich ook over patiënten met dementie en verwante neurocognitieve stoornissen, vooral binnen de ouderenpsychiatrie. Dementie is immers ook een in de DSM-5 geclassificeerde psychiatrische stoornis. Veelal was de inzet van de ggz daarbij van korte duur en beperkte omvang, omdat gedwongen opname uitsluitend tot stand kon komen via beoordeling door een psychiater. Dan was de enige interventie een beperkt onderzoek van de omstandigheden van de patiënt 
(gevaarscriteria), het opmaken van een geneeskundige verklaring en het regelen van een verpleeghuisbed.

\section{Veilig en verantwoord}

Er waren ook ggz-instellingen die daar méér werk van maakten. $Z \mathrm{ij}$ boden onderzoek en behandeling bij gedragsproblemen samenhangend met neurocognitieve stoornissen, vooral bij meer complexe beelden, soms ook in combinatie met andere - comorbide - psychiatrische stoornissen. Ze gaven de bemoeizorg (waarover later meer) die daarbij soms nodig is vanwege zorgmijding of -weigering. Daarmee lukte het sociaalpsychiatrisch verpleegkundigen en verpleegkundig specialisten ggz in veel gevallen een aanvraag voor een gedwongen opname met een rechterlijke machtiging $(\mathrm{RM})$ om te buigen naar passende zorg op vrijwillige basis. Aan die praktijk van specialistische bemoeizorg bij dementie lijkt een eind te zijn gekomen, nu de ggz die patiëntengroep heeft afgestoten. De belangrijkste reden is dat binnen de Wzd geen psychiater meer nodig is om gedwongen opname tot stand te brengen; de specialist ouderengeneeskunde (SO) of arts voor verstandelijke gehandicapten (AVG) kan dit doen. In de discussie rond de Wzd wordt veel gesproken over gedwongen opname met inbewaringstelling (IBS) of RM en de rol daarbij van de SO als Wzd-functionaris. De grootse uitdaging in de nieuwe wetgeving is echter niet het (doen) opnemen van mensen met dementie, maar het voorkomen daarvan. Eventueel met inzet van onvrijwillige zorg in de thuissituatie. In dit segment van zorg komen twee uitgangspunten van de Wzd samen die op het eerste gezicht met elkaar in tegenspraak zijn: het voorkomen of verminderen van onvrijwillige zorg én het toepassen daarvan, waar dat veilig en verantwoord mogelijk is om ernstig(er) nadeel te voorkomen. Voorwaar geen eenvoudige opdracht.

\section{Zorgmijding of weigering}

Het ernstig nadeel - kernbegrip uit de Wzd - dat voortkomt uit de stoornis dementie, komt in de regel niet uit de lucht vallen. Meestal zijn er al langer signalen en gebeurtenissen die maken dat meer of andere zorg nodig is om ernstig

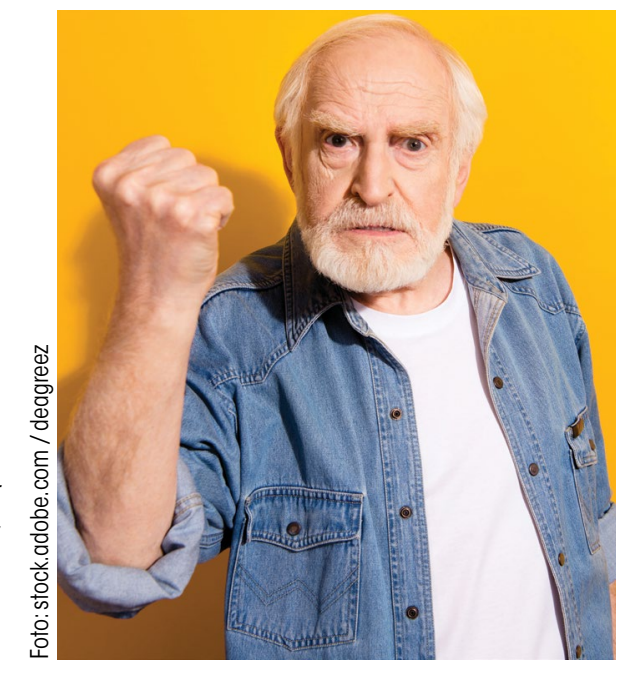

nadeel te voorkomen. Die signalen komen bij de mantelzorgers, thuiszorg, huisarts of casemanagers dementie. Als er adequate zorg beschikbaar komt en wordt toegelaten, is er in principe geen probleem. Ook niet als die zorg uiteindelijk niet meer thuis kan worden geboden, maar in een instelling. Als echter de betrokken patiënt noodzakelijke zorg afhoudt of weigert, komt er een moment waarop de huisarts, eventueel na inzet van eerstelijnsconsultatie of geriatrisch assessment, zal moeten besluiten dat 'het zo niet langer kan' en er op meer zorg moet worden aangedrongen. Desnoods tegen de wil van de betrokkene.

\section{Bemoeibalans}

Bemoeizorg is een begrip uit de psychiatrische verpleegkunde dat wordt toegepast bij patiënten die vanwege hun stoornis ernstig risico lopen of veroorzaken, maar daar zelf geen besef van hebben of het ontkennen. Het is erop gericht samen met de betrokken patiënt en diens omgeving te zoeken naar passende zorg, óók waar die niet op voorhand wordt gewenst of verdragen, maar wel noodzakelijk is. In Vlaanderen wordt het ook wel 'aanklampende zorg' genoemd. Het begint met contact maken en het opbouwen van een vertrouwensrelatie gericht op inzicht in de (eigen) problematiek en het verdragen van hulp, zorg en behandeling. Bij (verdenking van) dementie kan het toewerken naar specifiek onderzoek, thuiszorg, dagopvang of verpleeghuisopname daarvan deel uitmaken. Veel aandacht wordt besteed aan (systeem)communica- tie, psycho-educatie en mantelzorgondersteuning. Vaak is hierbij sprake van een creatieve en persoonlijke aanpak, met respect voor autonomie en eigenheid van de patiënt, maar zonder de risico's uit het oog te verliezen. Begrenzen en doorpakken kan daar deel van uitmaken. Het gaat daarbij om het vinden van een balans op het continuüm tussen verwaarlozing en bevoogding. De interventies verlopen van beschikbaar zijn, informeren en adviseren, via onderhandelen, overhalen of verleiden, naar aandringen en druk uitoefenen. Als dat niet volstaat, kan onder de Wzd nu ook onvrijwillige ambulante zorg worden overwogen. Dan kan door de huisarts een Wzd-functionaris worden ingeschakeld om te toetsen of daar reden voor is en een zorgverantwoordelijke worden aangesteld die ervoor zorgt dat het Wzd-stappenplan wordt gevolgd. Dit is nog een onontgonnen terrein. Wie kan hier bijvoorbeeld de rol van zorgverantwoordelijke vervullen? Maar het biedt wellicht nieuwe mogelijkheden voor opname-voorkomende interventies bij betere waarborgen voor bescherming van de persoonlijke levenssfeer van de betrokkene.

\section{Praktijk van onvrijwillige zorg}

Bemoeizorg en ambulante onvrijwillige zorg vergen intensieve en inventieve inzet van bekwame en betrokken hulpverleners. Behalve door de huisarts die de regie voert, eventueel met consultatie van een SO, zal deze zorg vooral worden uitgevoerd door verpleegkundigen. Binnen de ggz waren dit sociaal-psychiatrisch verpleegkundigen, binnen de sector verpleging en verzorging $(V \& V)$ wellicht casemanagers dementie en/of gespecialiseerde wijkverpleegkundigen. Vaak zal het mogelijk zijn hiermee passende zorg tot stand te brengen, bij voorkeur op vrijwillige basis.

Nieuw is dat onder de Wzd nu ook besloten kan worden ambulant onvrijwillige interventies in te zetten, die bij zorgmijding en -weigering uitkomst kunnen bieden. Bijvoorbeeld:

- toelaten van zorgverleners;

- uitoefenen van toezicht (bijvoorbeeld op hygiëne);

- toestaan van controles en onderzoek (van de inhoud van de koelkast tot 
bloedonderzoek of neuropsychologisch onderzoek);

- toestaan van maaltijdvoorziening of huishoudelijke hulp;

- inperken van bewegingsvrijheid (bijvoorbeeld niet meer 's avonds de straat op gaan), eventueel met controle via domotica;

- voorkomen van gevaar door bijvoorbeeld het afsluiten van gas of inname van autosleutels;

- zelfs het verplicht deelnemen aan dagactiviteiten buitenshuis wordt mogelijk.

Veel hiervan behoort al tot het arsenaal aan interventies van de (bemoei)zorg, maar nu is er een wettelijke basis voor. Daarmee kan ook het beginsel van subsidiariteit worden gediend. Dit houdt in dat eerst dergelijke - minder ingrijpende - maatregelen worden ingezet en pas bij niet kunnen naleven daarvan als ultimum remedium kan worden besloten tot een gedwongen opname om ernstig nadeel te voorkomen. Of dat veilig en verantwoord kan is nog ongewis.

\section{Subsidiariteit}

Als het ernstig nadeel niet kan worden voorkomen, ook niet via ambulante onvrijwillige zorg, en de teloorgang van een patiënt met dementie aanleiding geeft tot gedwongen opname, moet dit goed worden beargumenteerd en gedocumenteerd ten behoeve van het Centrum Indicatiestelling Zorg (CIZ) en de rechtbank. Veelal zal dit worden gedaan door de casemanager dementie of de wijkverpleegkundige, onder regie van de huisarts. Bij een beoordeling voor onvrijwillige opname zal het principe van subsidiariteit zwaar wegen. Oftewel: pas inzetten als andere, minder ingrijpende maatregelen hebben gefaald. Het opbouwen van een dossier en het eventueel volgen van het stappenplan Wzd hierin vergen tijd en precisie. Een besluit tot onvrijwillige opname vergt ook goede communicatie met de mantelzorgers. Het met elkaar daarover op één lijn komen is een voorwaarde voor succes. Als het besluit tot onvrijwillige opname genomen is, moet de zorg gewoon doorgaan. De procedure zal weken duren. Als de zitting van de rechtbank gepland is, zullen ook de advocaat en de cliëntenvertrouwenspersoon (CVP) gefaciliteerd moeten worden. Zo nodig zal een tolk moeten worden geregeld. Tevens zal een inschatting gemaakt moeten worden van de eventuele risico's bij de zitting. Risico's bijvoorbeeld op agressie en verzet, maar ook op risico's bij vervuilde of slecht toegankelijke woningen.

\section{Ontvluchting of verzet}

Op de dag van de zitting zal iemand regie moeten voeren over de omstandigheden, de aanwezigen, de vervolgafspraken en de reactie van de patiënt op de uitspraak. In de huidige praktijk is dat veelal de casemanager dementie of de wijkverpleegkundige in samenspraak met de huisarts.

Volgens de Wzd moet de patiënt bij een IBS binnen 24 uur worden opgenomen. Bij een RM stelt de Wzd enkel een maximale geldigheidsduur van de machtiging: vier weken na het besluit. In de

\section{'De grootse uitdaging in de nieuwe wet is opname van mensen met dementie voorkomen'}

Bopz-praktijk was dat 14 dagen, maar werd er veelal op aangestuurd de opname zo snel mogelijk te effectueren. Het gaat hier tenslotte om een patiënt die groot risico loopt en zich tegen opname verzet. Het risico op ontvluchting of suïcide kan sterk toenemen na de uitspraak. Ook dat moet worden beoordeeld en de patiënt kan in dat geval niet meer alleen worden gelaten. Veelal zijn ook de betrokken (mantel)zorgers al aan het eind van hun Latijn. Voor de opname zelf zal vervoer geregeld moeten worden, eventueel met ambulance, zeker als er actief verzet is. In dat geval kan ingrijpmedicatie of politiebijstand nodig zijn. Ook zullen de medische verklaring en de beschikking van de rechtbank op papier aanwezig moeten zijn, zowel tijdens het vervoer per ambulance als bij de opname in het ontvangende verpleeghuis. Voor de $\mathrm{V} \& \mathrm{~V}$-sector zijn dit nieuwe taken en verantwoordelijkheden.

\section{Stand van zaken}

De V\&V-sector is terughoudend en ook niet verplicht tot het verlenen van bemoeizorg of ambulante onvrijwillige zorg. Patiënten hebben er ook geen afdwingbaar recht op. Waar de sector dergelijke zorg wel gaat leveren of faciliteren, zijn er nog flink wat haken en ogen. Zowel organisatorisch, inhoudelijk als personeel en financieel. De bestuurlijke afspraken tussen de ggz, psychogeriatrie en de verstandelijk gehandicaptenzorg over de samenwerking bij crisis en beoordeling voor gedwongen opname (ministerie VWS, dec. 2020) zijn medio 2021 geëvalueerd. Ook de V\&VN-sectie wijkverpleegkundigen geeft aan dat de randvoorwaarden van de wet voor de ambulante praktijk nog steeds niet op orde zijn. Dit betekent dat zij verpleegkundigen en verzorgenden in de wijk nog adviseert geen onvrijwillige zorg toe te passen totdat er meer duidelijkheid is over de uitvoerbaarheid.

Daarom is het verheugend dat vanuit branchevereniging ActiZ in opdracht van VWS in de tweede helft van 2021 zes 'praktijktuinen' van start zijn gegaan om de Wzd ook ambulant te implementeren en ermee te experimenteren. Daarbij kunnen ook regionale verschillen bestaan. Relevante vragen dienen zich dan aan. Voorbeelden: (1) Kan onvrijwillige zorg thuis worden toegepast én worden teruggedrongen? (2) Welke multidisciplinaire organisatiestructuur is daarbij het best passend? (3) Hoe kunnen de verantwoordelijkheden tussen betrokken disciplines het best worden verdeeld?

(4) Is het stappenplan Wzd ook ambulant toepasbaar? (5) Leidt de inzet van bemoeizorg en onvrijwillige zorg tot vermindering van het aantal gedwongen opnames? (6) Welke onvrijwillige interventies worden daarbij ingezet en hoe doelmatig zijn die?

De Praktijktuinen hebben een looptijd tot uiterlijk december 2022. Ze zullen inzichten en kennis verschaffen die helpend zijn bij de ambulante implementatie van de Wzd.

\section{REFERENTIE}

1. Ministerie van Volksgezondheid, Welzijn en Sport. Informatiepunt

'Dwang in de zorg'.

www.dwangindezorg.nl. 